\title{
Erratum to pathological analysis and surgical modalities selection of cT1NOMO solitary papillary thyroid carcinoma in the isthmus
}

\section{Editorial Office}

Gland Surgery

Correspondence to: Editorial Office. Gland Surgery. Email: editor@glandsurgery.org.

doi: $10.21037 / g s-2021-07$

View this article at: https://dx.doi.org/10.21037/gs-2021-07

Erratum to: Gland Surg 2021;10:2445-54

In issue Vol 10, No 8 (August 2021) of Gland Surgery, the paper "Pathological analysis and surgical modalities selection of cT1N0M0 solitary papillary thyroid carcinoma in the isthmus" by Zhang LZ, Xu JJ, Ge XY, et al. (1) was published with four errors.

In the abstract part, "Multiple logistic analysis suggested that age over 55 years [odds ratio $(\mathrm{OR})=11.90,95 \%$ CI: 1.36 to 104.03, $\mathrm{P}=0.025$ ], tumor size greater than $0.55 \mathrm{~cm}(\mathrm{OR}=4.16,95 \% \mathrm{CI}: 1.28$ to $13.52, \mathrm{P}=0.018)$ " should be corrected as "Multiple logistic analysis suggested that age under 55 years old [odds ratio (OR) $=11.90,95 \%$ CI: 1.36 to $104.03, \mathrm{P}=0.025$ ], tumor size greater than $0.55 \mathrm{~cm}(\mathrm{OR}=4.16,95 \% \mathrm{CI}: 1.28$ to $13.52, \mathrm{P}=0.018)$ ".

In the abstract part, "Central lymph node dissection is recommended for patients who are prone to have central occult lymph node metastases with tumor size $\geq 55 \mathrm{~cm}$, older than 55 years, and without nodular goiter." should be corrected as "Central lymph node dissection is recommended for patients who are prone to have central occult lymph node metastases with tumor size $\geq 0.55 \mathrm{~cm}$, age under 55 years, and without nodular goiter."

In the conclusion part, "Among such patients, central lymph node dissection was recommended for those who were prone to have central occult lymph node metastases with tumor size $\geq 55 \mathrm{~cm}$, age under 55 years, and without nodular goiter." should be corrected as "Among such patients, central lymph node dissection was recommended for those who were prone to have central occult lymph node metastases with tumor size $\geq 0.55 \mathrm{~cm}$, age under 55 years, and without nodular goiter.”

Click here to view the updated version of the article.

Open Access Statement: This is an Open Access article distributed in accordance with the Creative Commons AttributionNonCommercial-NoDerivs 4.0 International License (CC BY-NC-ND 4.0), which permits the non-commercial replication and distribution of the article with the strict proviso that no changes or edits are made and the original work is properly cited (including links to both the formal publication through the relevant DOI and the license). See: https://creativecommons.org/licenses/by-nc$\mathrm{nd} / 4.0 \%$. 


\section{References}

1. Zhang LZ, Xu JJ, Ge XY, et al. Pathological analysis and surgical modalities selection of cT1N0M0 solitary papillary thyroid carcinoma in the isthmus. Gland Surg 2021;10:2445-54.

Cite this article as: Editorial Office. Erratum to pathological analysis and surgical modalities selection of cT1N0M0 solitary papillary thyroid carcinoma in the isthmus. Gland Surg 2021;10(11):3167-3168. doi: 10.21037/gs-2021-07 